\title{
Front Matter: Volume 8900
}

, "Front Matter: Volume 8900," Proc. SPIE 8900, Millimetre Wave and Terahertz Sensors and Technology VI, 890001 (25 October 2013); doi: $10.1117 / 12.2035264$

SPIE. Event: SPIE Security + Defence, 2013, Dresden, Germany 


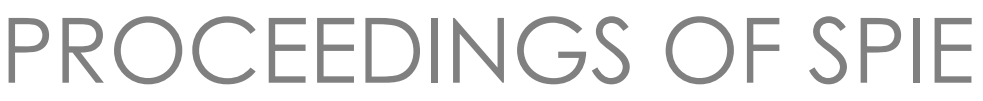

\title{
Millimetre Wave and Terahertz Sensors and Technology VI
}

\author{
Neil Anthony Salmon \\ Eddie L. Jacobs \\ Editors
}

24-25 September 2013

Dresden, Germany

Sponsored by

SPIE

Cooperating Organisations

Fraunhofer-Gesellschaft (Germany)

Published by

SPIE 
The papers included in this volume were part of the technical conference cited on the cover and title page. Papers were selected and subject to review by the editors and conference program committee. Some conference presentations may not be available for publication. The papers published in these proceedings reflect the work and thoughts of the authors and are published herein as submitted. The publisher is not responsible for the validity of the information or for any outcomes resulting from reliance thereon.

Please use the following format to cite material from this book:

Author(s), "Title of Paper," in Millimetre Wave and Terahertz Sensors and Technology VI, edited by Neil Anthony Salmon, Eddie L. Jacobs, Proceedings of SPIE Vol. 8900 (SPIE, Bellingham, WA, 2013) Article CID Number.

ISSN: 0277-786X

ISBN: 9780819497697

Published by

SPIE

P.O. Box 10, Bellingham, Washington 98227-0010 USA

Telephone +1 3606763290 (Pacific Time) · Fax +1 3606471445

SPIE.org

Copyright @ 2013, Society of Photo-Optical Instrumentation Engineers.

Copying of material in this book for internal or personal use, or for the internal or personal use of specific clients, beyond the fair use provisions granted by the U.S. Copyright Law is authorized by SPIE subject to payment of copying fees. The Transactional Reporting Service base fee for this volume is $\$ 18.00$ per article (or portion thereof), which should be paid directly to the Copyright Clearance Center (CCC), 222 Rosewood Drive, Danvers, MA 01923. Payment may also be made electronically through CCC Online at copyright.com. Other copying for republication, resale, advertising or promotion, or any form of systematic or multiple reproduction of any material in this book is prohibited except with permission in writing from the publisher. The CCC fee code is 0277-786X/13/\$18.00.

Printed in the United States of America.

Publication of record for individual papers is online in the SPIE Digital Library.

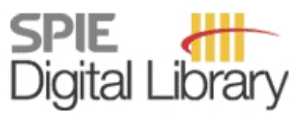

SPIEDigitalLibrary.org

Paper Numbering: Proceedings of SPIE follow an e-First publication model, with papers published first online and then in print and on CD-ROM. Papers are published as they are submitted and meet publication criteria. A unique, consistent, permanent citation identifier (CID) number is assigned to each article at the time of the first publication. Utilization of CIDs allows articles to be fully citable as soon as they are published online, and connects the same identifier to all online, print, and electronic versions of the publication. SPIE uses a six-digit CID article numbering system in which:

- The first four digits correspond to the SPIE volume number.

- The last two digits indicate publication order within the volume using a Base 36 numbering

system employing both numerals and letters. These two-number sets start with 00, 01, 02, 03, 04, $05,06,07,08,09,0 A, 0 B \ldots 0 Z$, followed by 10-1Z, 20-2Z, etc.

The CID Number appears on each page of the manuscript. The complete citation is used on the first page, and an abbreviated version on subsequent pages. Numbers in the index correspond to the last two digits of the six-digit CID Number. 


\section{Contents}

vii Conference Committee

ix Introduction

\section{OPERATIONAL SYSTEMS}

890002 Reflect-array based mm-wave people screening system (Invited Paper) [8900-1]

B. N. Lyons, E. Entchev, M. K. Crowley, Smiths Detection Ireland Ltd. (Ireland)

890003 A fast imaging MMW radiometer system for security and safety applications [8900-2]

S. Dill, M. Peichl, German Aerospace Ctr. (Germany)

890004 An aviation security (AVSEC) screening demonstrator for the detection of non-metallic threats at 28-33 GHz [8900-3]

N. A. Salmon, N. Bowring, S. Hutchinson, M. Southgate, D. O'Reilly, Manchester Metropolitan Univ. (United Kingdom)

890005 A feasibility study into the screening and imaging of hand luggage for threat items at 35 GHz using an active large aperture $(1.6 \mathrm{~m})$ security screening imager [8900-4]

N. J. Bowring, D. O'Reilly, N. A. Salmon, D. A. Andrews, N.-D. Rezgui, S. W. Harmer, Manchester Metropolitan Univ. (United Kingdom)

890006 History and challenges of passive millimeter wave imaging [8900-30]

A. N. Pergande, Lockheed Martin Corp. (United States)

\section{OPERATIONAL SYSTEMS II}

890007 Motion effects in multistatic millimeter-wave imaging systems (Invited Paper) [8900-5] A. Schiessl, S. S. Ahmed, Rohde \& Schwarz GmbH \& Co. KG (Germany); L.-P. Schmidt, Friedrich-Alexander-Univ. Erlangen-Nürnberg (Germany)

$890008 \quad$ A W-band passive imaging system implemented with rotating diffraction antenna technology [8900-6]

S. Shylo, Y. Sydorenko, Usikov Institute of Radiophysics and Electronics (Ukraine);

D. Wheeler, Radio Physics Solutions Inc. (United States); D. Dundonald, Radio Physics Solutions Ltd. (United Kingdom)

890009 Review of the characteristics of $384 \times 288$ pixel THz camera for see-through imaging [8900-7] L. Marchese, M. Terroux, F. Genereux, B. Tremblay, M. Bolduc, A. Bergeron, INO (Canada)

8900 OA Development of an ultra wide band microwave radar based footwear scanning system [8900-8]

N. D. Rezgui, N. J. Bowring, D. A. Andrews, S. W. Harmer, M. J. Southgate, D. O'Reilly, Manchester Metropolitan Univ. (United Kingdom) 
IMAGE PROCESSING AND TECHNIQUES

8900 OD Target decomposition and polarimetric radar applied to concealed threat detection [8900-10]

D. O'Reilly, N. Bowring, N. D. Rezgui, D. Andrews, Manchester Metropolitan Univ. (United Kingdom)

8900 OE A calibration concept for passive MW imaging using beam steering by frequency shift and aperture synthesis [8900-11]

E. Schreiber, M. Peichl, M. Jirousek, German Aerospace Ctr. (Germany)

8900 OF Multispectral THz-VIS passive imaging system for hidden threats visualization [8900-12]

M. Kowalski, N. Palka, M. Szustakowski, Military Univ. of Technology (Poland)

8900 OG Expanded opportunities of THz passive camera for the detection of concealed objects [8900-13]

V. A. Trofimov, V. V. Trofimov, I. E. Kuchik, Lomonosov Moscow State Univ. (Russian Federation)

$8900 \mathrm{OH} \quad$ Terahertz time-domain spectroscopy for distinguishing different kinds of gunpowder [8900-14]

T. Gavenda, V. Křesálek, Tomas Bata Univ. of Zlin (Czech Republic)

\section{EMERGING SYSTEMS}

8900 OM T-SENSE a millimeter wave scanner for letters (Invited Paper) [8900-19]

D. Nüßler, S. Heinen, Fraunhofer FHR (Germany); T. Sprenger, D. Hübsch, T. Würschmidt, Hübner GmbH (Germany)

8900 ON Near-field and three-dimensional aperture synthesis imaging [8900-20]

N. A. Salmon, N. Bowring, Manchester Metropolitan Univ. (United Kingdom)

890000 Impulse radar imaging system for concealed object detection [8900-21]

F. J. W. Podd, M. David, G. Iabal, F. Hussain, D. Morris, E. Osakue, Y. Yeow, S. Zahir,

D. W. Armitage, A. J. Peyłon, The Univ. of Manchester (United Kingdom)

$8900 \mathrm{OP} \quad$ THz remote sensing with $\mu \mathrm{m}$ resolution [8900-22]

J. Trontelj, A. Sešek, Univ. of Ljubljana (Slovenia) and Ctr. of Excellence, NAMASTE

(Slovenia); A. Švigelj, Ctr. of Excellence, NAMASTE (Slovenia) and Letrika Lab d.o.o.

(Slovenia) 
8900 OR Broadband THz detection and homodyne mixing using GaAs high-electron-mobility transistor rectifiers (Invited Paper) [8900-24]

S. Preu, S. Regensburger, Friedrich-Alexander-Univ. Erlangen-Nürnberg (Germany); S. Kim, Tanner Research, Inc. (United States); M. Mittendorff, S. Winnerl, Helmholtz-Zentrum Dresden-Rossendorf e. V. (Germany); S. Malzer, Friedrich-Alexander-Univ. ErlangenNürnberg (Germany); H. Lu, P. G. Burke, A. C. Gossard, Univ. of California, Santa Barbara (United States); H. B. Weber, Friedrich-Alexander-Univ. Erlangen-Nürnberg (Germany); M. S. Sherwin, Univ. of California, Santa Barbara (United States)

8900 OS Preliminary fabrication and characterization of low-leakage hybrid coaxial cable [8900-25] A. Rudnitsky, D. Elbaz, Z. Zalevsky, Bar-llan Univ. (Israel)

\section{POSTER SESSION}

8900 0T The evaluation of THz-VIS fused images [8900-26]

M. Kowalski, N. Palka, M. Szustakowski, Military Univ. of Technology (Poland)

8900 OU Detection of the $\mathrm{THz}$ waves from the $5 \mathrm{~m}$ distance [8900-27]

M. Walczakowski, N. Palka, M. Szustakowski, Military Univ. of Technology (Poland);

A. Czerwinski, M. Sypek, Warsaw Univ. of Technology (Poland)

$8900 \mathrm{OV} T \mathrm{THz}$ devices evaluation in a time domain spectroscopy system at $1.55 \mu \mathrm{m}$ pulse excitation [8900-28]

I. Kostakis, The Univ. of Manchester (United Kingdom); A. Zandieh, D. Hailu, D. Saeedkia, TeTechS Inc. (Canada); M. Missous, The Univ. of Manchester (United Kingdom)

Author Index 


\section{Conference Committee}

Symposium Chair

David H. Titterton, Defence Science and Technology Laboratory

(United Kingdom)

Symposium Cochair

Reinhard Ebert, Fraunhofer IOSB, Institute of Optronics, System

Technologies and Image Exploitation (Germany)

Conference Chairs

Neil Anthony Salmon, MMW Sensors Ltd. (United Kingdom)

Eddie L. Jacobs, University of Memphis (United States)

Conference Program Committee

Amir Abramovich, Ariel University Center of Samaria (Israel)

Nicholas J. Bowring, Manchester Metropolitan University

(United Kingdom)

Markus Peichl, Deutsches Zentrum für Luft- und Raumfahrt e.V. (Germany)

Douglas T. Petkie, Wright State University (United States)

Christopher A. Schuetz, Phase Sensitive Innovations, Inc. (United States)

Session Chairs

1 Operational Systems

Stephen Dill, Deutsches Zentrum für Luft- und Raumfahrt e.V. (Germany)

Neil Anthony Salmon, MMW Sensors Ltd. (United Kingdom)

2 Operational Systems II

Amir Abramovich, Ariel University Center of Samaria (Israel)

Eddie L. Jacobs, University of Memphis (United States)

3 Image Processing and Techniques

Eddie L. Jacobs, University of Memphis (United States)

Douglas T. Petkie, Wright State University (United States)

4 Medical and Biological Sensors

Nicholas J. Bowring, Manchester Metropolitan University

(United Kingdom)

Neil Anthony Salmon, MMW Sensors Ltd. (United Kingdom) 
5 Emerging Systems

Nicholas J. Bowring, Manchester Metropolitan University

(United Kingdom)

Christopher A. Schuetz, Phase Sensitive Innovations, Inc. (United States)

6 Devices

Amir Abramovich, Ariel University Center of Samaria (Israel)

Markus Peichl, Deutsches Zentrum für Luft- und Raumfahrt e.V. (Germany) 


\section{Introduction}

The $6^{\text {th }}$ international conference in the Millimetre Wave and Terahertz Sensors and Technology conference series, as part of the SPIE Europe Security + Defence meeting (held in Dresden this year), presents continued innovations in technologies and their applications for this frequency band.

In this year's conference, commercial security screening portals are presented which operate actively over the $20-80 \mathrm{GHz}$ band, showing some spectacular imagery and making headway with legislative authorities for screening. Also in the lower frequency part of the millimetre wave band a novel active system for the security screening of shoes is introduced to aid rapid throughput of passengers at airports. Polarimetric discrimination techniques from the active remote sensing community are being exploited for threat classification in security screening sensors, which only collect a small number of cross-range pixels over a subject. In the band of a few hundred $\mathrm{GHz}$ compact and closed-cycle cryogenically cooled focal plane array detectors are showing promising performance by offering large numbers of pixels with excellent noise performance. These would be well suited for stand-off security screening imagers. The use of Principal Component Analysis is proving useful in the analysis of terahertz (>0.3 THz) spectra to provide a means to identify suspicious materials contained within letters and parcels, whilst VOx microbolometer cameras (initially developed for the infra-red band) are providing imagery at a few $\mathrm{THz}$ of contents. The technology provides a complementary detection capability to $x$ ray security screening systems for critical types of material. The development of terahertz technology for biomedical applications shows steady progress with interest in nano-particle probes to enhance terahertz signatures from organic tissue.

The conference will continue to push to present emerging technologies which increase system performance and drive down system costs whilst highlighting customer drivers and making known signatures, phenomenology and capabilities in the millimetre to terahertz band. The $7^{\text {th }}$ international conference in this series will take place in Amsterdam 22 th $-25^{\text {th }}$ September 2014.

Neil Anthony Salmon Eddie L. Jacobs 